\begin{tabular}{|c|c|c|c|c|c|c|c|c|}
\hline \multicolumn{3}{|c|}{$\begin{array}{l}\text { 2. To: (Receiving Organization) } \\
\text { Distribution }\end{array}$} & \multicolumn{2}{|c|}{$\begin{array}{l}\text { 3. From: (Originating Organization) } \\
\text { SNF Project }\end{array}$} & \multicolumn{4}{|c|}{$\begin{array}{r}\text { 4. Related EDT No.: } \\
\text { N/A }\end{array}$} \\
\hline \multicolumn{3}{|c|}{$\begin{array}{l}\text { 5. Proj./Prog./Dept./Div.: } \\
\text { Spent Nuclear Fuel Project }\end{array}$} & \multicolumn{2}{|c|}{$\begin{array}{l}\text { 6. Design Authority/ Design Agent/Cog. } \\
\text { Engr.: } \\
\text { C. Van Katwijk }\end{array}$} & \multicolumn{4}{|c|}{$\begin{array}{r}\text { 7. Purchase Order No.: } \\
\text { N/A } \\
\end{array}$} \\
\hline \multirow{2}{*}{\multicolumn{5}{|c|}{$\begin{array}{l}\text { 8. Originator Remarks: } \\
\text { N/A }\end{array}$}} & \multicolumn{4}{|c|}{$\begin{array}{l}\text { 9. Equip./Component No.: } \\
\text { N/A }\end{array}$} \\
\hline & & & & & \multicolumn{4}{|c|}{$\begin{array}{l}\text { 10. System/BIdg./Facility: } \\
\text { Spent Nuclear Facility }\end{array}$} \\
\hline \multirow{3}{*}{\multicolumn{5}{|c|}{ 4. Design Baseline Document }} & \multicolumn{4}{|c|}{$\begin{array}{l}\text { 12. Major Assm. Dwg. No.: } \\
\text { N/A }\end{array}$} \\
\hline & & & & & \multicolumn{4}{|c|}{$\begin{array}{l}\text { 13. Permit/Permit Application No.: } \\
\text { N/A }\end{array}$} \\
\hline & & & & & \multicolumn{4}{|c|}{$\begin{array}{l}\text { 14. Required Response Date: } \\
\text { N/A }\end{array}$} \\
\hline \multicolumn{2}{|l|}{15.} & \multicolumn{3}{|c|}{ DATA TRANSMITTED } & (F) & (G) & (H) & (I) \\
\hline $\begin{array}{l}\text { (A) } \\
\text { Item } \\
\text { No. }\end{array}$ & (B) Document/Drawing No. & $\begin{array}{l}\text { (C) } \\
\text { Sheet } \\
\text { No. }\end{array}$ & $\begin{array}{l}\text { (D) } \\
\text { Rev. } \\
\text { No. }\end{array}$ & $\begin{array}{l}\text { (E) Title or Description of Data } \\
\text { Transmitted }\end{array}$ & $\begin{array}{l}\text { Approval } \\
\text { Desig- } \\
\text { Nator }\end{array}$ & $\begin{array}{l}\text { Reason } \\
\text { for } \\
\text { Trans- } \\
\text { mittal }\end{array}$ & $\begin{array}{l}\text { Origi- } \\
\text { nator } \\
\text { Dispo- } \\
\text { sition }\end{array}$ & $\begin{array}{l}\text { Receiv- } \\
\text { er } \\
\text { Dispo- } \\
\text { sition }\end{array}$ \\
\hline 1 & SNF-3927 & & 0 & $\begin{array}{l}\text { Ashcroft Pressure Switch-Monitor for } \\
\text { Low SCHe Supply Bottle Pressure }\end{array}$ & $\mathrm{Q}$ & 2 & 1 & N/A \\
\hline & & & & & & & & \\
\hline & & & & & & & & \\
\hline & & & & & & & & \\
\hline & & & & & & & & \\
\hline
\end{tabular}

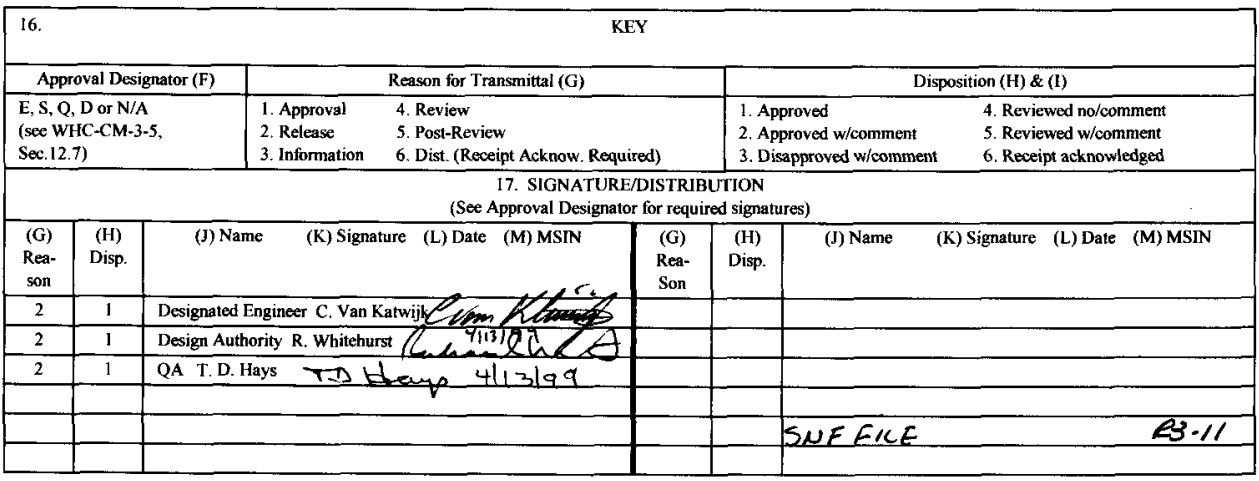

\begin{tabular}{|l|l|l|l|}
\hline 18. & $\begin{array}{l}20 . \\
\text { 21. DOE APPROVAL (if required) } \\
\text { Ctrl. No. } \\
\text { [1 Approved }\end{array}$ \\
\hline $\begin{array}{l}\text { Signature of EDt } \\
\text { Originator }\end{array}$ & $\begin{array}{l}\text { Approved w/comments } \\
\text { [. Choho Disapproved w/comments }\end{array}$ \\
\hline
\end{tabular}




\section{Ashcroft Pressure Switch - Monitor for Low SCHe Supply Bottle Pressure}

Carl Van Katwijk

Numatec Hanford Co, Richland, WA 99352

U.S. Department of Energy Contract DE-AC06-96RL13200

EDT/ECN: 626276

Org Code: $2 \mathrm{G} 300$

B\&R Code: 39EW40400
UC: 620

Charge Code: 105559/A000

Total Pages: 13

Key Words: Supply Bottle Pressure

Abstract: Ashcroft Pressure Switch - Monitor for Low SCHe Supply Bottle Pressure CGI-SNF-D-13-P5-030

TRADEMARK DISCLAIMER. Reference herein to any specific commercial product, process, or service by trade name, trademark, manufacturer, or otherwise, does not necessarily constitute or imply its endorsement, recommendation, or favoring by the United States Government or any agency thereof or its contractors or subcontractors.

Printed in the United States of America. To obtain copies of this document, contact: Document Control Services, P.O. Box 950, Mailstop H6-08, Richland WA 99352, Phone (509) 372-2420; Fax (509) 376-4989.

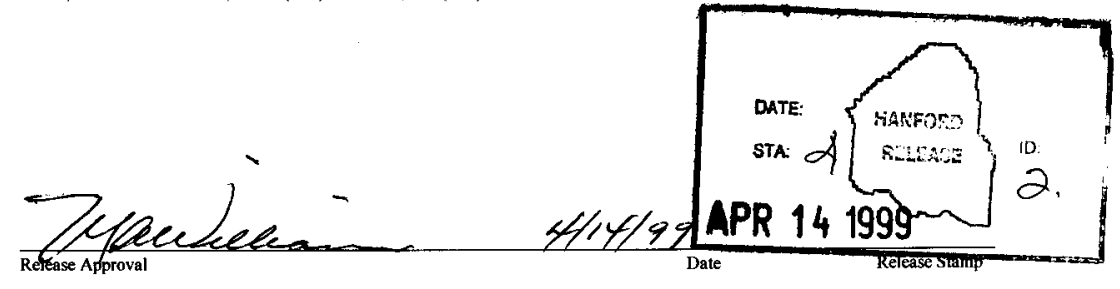




\begin{tabular}{|l|l|l|}
\hline Item No.: NA & Manufacturer. & Supplier: \\
\hline Mif. Part/Model No: & Supplier's PN:
\end{tabular}

Part Description:

\section{End Use Description:}

\begin{tabular}{|c|c|c|c|}
\hline $\begin{array}{l}\text { Equipment No.: SCHe- } \\
\text { PSL-5*03,5*22, } \\
5^{*} 42,5^{*} 62\end{array}$ & $\begin{array}{l}\text { Specification No.: W-441- } \\
\text { P5, Rov. } 2\end{array}$ & $\begin{array}{l}\text { Manufacturer. Ashcroft } \\
\text { Instrument Division }\end{array}$ & Past P.O. No.: NA \\
\hline $\begin{array}{l}\text { Manufacturer's Part/ Moddl } \\
\text { No.: LPS-N4-K-T-25- } \\
3000 \text { PSI. }\end{array}$ & \multicolumn{2}{|c|}{ Equipment Supplier (fi different from manufacturer): TBD } & $\begin{array}{l}\text { Equip. Supplier's Part No.: } \\
\text { NA }\end{array}$ \\
\hline
\end{tabular}

Component Description: These 0-3000 psig pressure switches are located in the SCHe helium supply lines at the pressure bottles and upstream of the PRV. The switches monitor the SCHe supply bottle pressure and are set to alarm at 2000 psig. There is one switch for each SCHe supply (4). 8.

1. Is the Item available from a catalog from a qualified NQA1 Engineer or BTR)?

l I YES (go to $\# 2$ below)

[X] NO (go to procedure step 5.3.2, proceed to decicate ilem.)

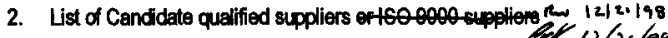
company name and type contact name $2 K 12 / 21 / 98$ phone NA

3. Recommended Procurement Strategy (coordinate with project CGl interface Engineer or BTR): NA

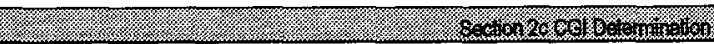

1. Question \#1: Is the ltem subject to design or specification requirements that are unique to nuclear facilities or activities?

[ ] YES (the item is not commercial grade)

[X] NO (continue)

2. Question \#2: Is the Item used in applications other than nudear facilities or activities?

I ] NO (the item is not commercial grade)

$[X]$ YES (continue) 
Commercial Grade Item Upgrade Dedication Form

ECN No. NA CGI No.CGI-SNF-D-13-P5-030

Rev. No. 0

Title: ASHCROFT PRESSURE SWTTCH - MONITOR FOR LOW SCHE SUPPLY BOTTLE PRESSURE

3. Question \#3: Is the Item ordered from manufacturer/supplier on the basis or specifications set forth in the manufacturers catalog?

[ ] NO (the ltem is not commercial grade)

[X] YES (continue)

[X] All three criteria have been satisfied. The Item meets the definition of commercial grade.

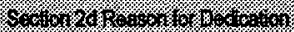

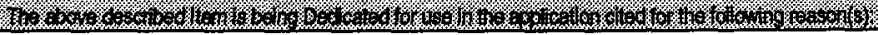

[X] ltem is being purchased from a non ESL manufacturer supplier as commercial grade to be used in a Safety Class epplication.

[ ] Item is being purchased from a non ESL manufacturer supplier as commercial grade to be used in a Safety Significant application.

I I Item was purchased from a non ESL manufacturer supplier as commercial grade to be used in a Safety Class application.

I I Item was purchased from a non ESL manufacturer supplier as commercial grade to be used in a Safety Significant application.

l I Other (like-for-like', similar, substitution, replacement evaluation)

\section{A. Part/Component Salety Function:}

1. SCHe Pressure Boundary Integrity- Prevents helium leakage from the SCHe System.

2. Maintain pressure boundary after Seismic event.

3.

B. Part/Component Functional Mode

Safety Function \#1:

[ ] Active - Mechanical or Electrical change of state is required to occur for the component to perform its safety function

[X] Passive - Change of state is not required for the component to perform its safety function Safety Function \#2:

[ ] Active - Mechanical or Electrical change of state is required to occur for the component to perform its safety function.

[X] Passive - Change of state is not required for the component to perform its safety function Safety Function \#3:

l ] Active - Mechanical or Electrical change of state is required to occur for the component to perform its safety function.

l ] Passive - Change of state is not required for the component to perform its safety function

C. Host Component Safety Function (if applicable):

1. NA

2.

3. 
Title: ASHCROFT PRESSURE SWITCH - MONITOR FOR LOW SCHE SUPPLY BOTTLE PRESSURE

D. Failure Mechanisms(s) and the effects on component or system safely function (see worksheet 1 ):

1. Fracture of the switch body or of the piping connection resulting in loss of helium from the sCHe supply.

2.

3.

4.

5.

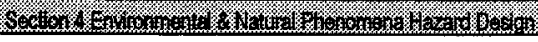

Environmental Qualification Requirect.

Yes [ ]

No $[\mathbf{X}]$

Environmental Condition B

If yes: Envirormental Qualification Requirements

Limiting Environmental Conditions:

Required Safety Functions:

Qualification Period:

Natural Phenomena Hazard (NPH) Design Required:

Yes $[\mathbf{X}]$

If yes: NPH Design Requirements

No [ ]

Performance Category: PC-3

NPH Design Reqts.: Seismic Condition B

HNF-PRO-97, Rev. 0

Required Safety Functions: Pressure Boundery

W-441-P5, Rev. 2 Integrity

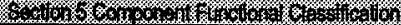

[X] Safety Class (SC)

I |General Service

[ ] Safety Significant (SS)

If part/component classification is diferent from host componentsystem, document basis.

\begin{tabular}{|c|c|c|}
\hline \multicolumn{3}{|c|}{ 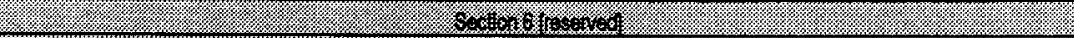 } \\
\hline 8 & 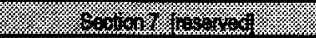 & \\
\hline \multicolumn{3}{|c|}{ 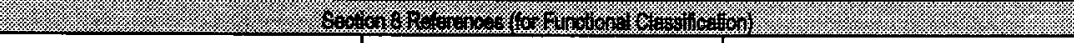 } \\
\hline National Codes/Standards: IEEE-344 & $\begin{array}{l}\text { Safety Analysis Report (SAR): } \\
\text { HNF-SD-SNF-SAR-002, Rev. } \\
\text { 4A }\end{array}$ & $\begin{array}{l}\text { Drawings: H-1-82165, Rev. } 2 \\
\text { HNF-SD-SNF-SEL-002, Rev. } 4 \\
\text { CVDF-SSD-003 }\end{array}$ \\
\hline
\end{tabular}

Vendor Manuals/Manufacturer/Supplier Information; Ashcroft Instrument Division, L Series Switches, Bulletin Se-12

Other: 
Commercial Grade Item Upgrade Dedication Form

ECN No. NA CGINo. CGI-SNF-D-13-P5-030

Rev. No. 0 SNP-3927

Page 4 of 12

Title: ASHCROFT PRESSURE SWITCH - MONITOR FOR LOW SCHe SUPPLY BOTTLE PRESSURE

\begin{tabular}{|c|c|c|c|c|}
\hline \\
\hline \begin{tabular}{l}
\multicolumn{1}{c}{ Critical Characteristics } \\
Verification Document: Vendor \\
Specifications, \\
HNF-SD-SNF-SEL-002, Rev. 4
\end{tabular} & Acceptance Criteria/Tolerances & $\begin{array}{l}\text { Acceptance } \\
\text { Method }\end{array}$ & ID & Function \\
\hline \multicolumn{5}{|c|}{ 1. Item Identification Critical Characteristics (necessary for reasonable assurance that the ltem delivered is the Item specified) } \\
\hline Nameplate Data & Per Vendor Manual & $1, \mathrm{IN}$ & $\mathbf{x}$ & \\
\hline Model Number & LPS-N4-K-T-25-3000 PSI & $1, \mathrm{IN}$ & $\underline{x}$ & \\
\hline Manufacturer & Asheroft Instruments & $1, \mathrm{lN}$ & $\mathbf{x}$ & \\
\hline Process Connection & $1 / 4$ Inch FNPT & $1, \mathrm{IN}$ & $\mathbf{x}$ & \\
\hline Pressure Range & 0-3000 Psig & $1, \mathrm{IN}$ & $\mathbf{x}$ & \\
\hline Enclosure & NEMA 4,4X & 1, IN & $\mathbf{x}$ & \\
\hline \multicolumn{5}{|c|}{ 2. Physical Critical Characteristics (necessary for reasonable assurance that the Item delivered is the Item specified) } \\
\hline Material, Body & Stainless Steal & $1, T$ & $\mathbf{x}$ & \\
\hline Material, Process Connection & Stainless Steel & $1, T$ & $\mathbf{x}$ & \\
\hline \multicolumn{5}{|c|}{$\begin{array}{l}\text { 3. Performance Critical Characteristics (necessary \& sufficient for reasonable assurance that the Item will perform its intended } \\
\text { safety function(s)) }\end{array}$} \\
\hline Pressure Boundery Integrity & $\begin{array}{l}\text { No Leakage at Test Pressure of } \\
\text { 3300 Psig. Note } 3 \text {. } \\
\end{array}$ & $1 . T$ & & $\mathbf{x}$ \\
\hline Setpoint/Repeatability & 2000 Psig $/+1-1 \%$ of Range & $1, T$ & & $x$ \\
\hline Environmantal & Note 1 & & & \\
\hline Seismic Condition B & Maintain Pressure Boundary & $1, T$ & & $\mathbf{x}$ \\
\hline Switch Contact Rating & $\begin{array}{l}\text { Nominal } 15 \text { Amps at } 120 \text { VAC. } \\
\text { Less Than } 0.5 \text { Volt Drop } \\
\text { Across Contacts } \\
\end{array}$ & 1.T & & $\mathbf{x}$ \\
\hline Insulation Resistance & $\begin{array}{l}\text { Greater Than } 10 \text { Megohm } \\
\text { Resistance to Ground }\end{array}$ & $1, T$ & & $\mathbf{x}$ \\
\hline \multicolumn{2}{|c|}{$\begin{array}{l}\text { 4. Notes and Legend } \\
\text { 1. The pressure switch and Tefion seals are not subject to } \\
\text { degradation at ambient conditions of } 40^{\circ} \mathrm{F} \text { and } 60 \% \text { RH or } \\
115^{\circ} \mathrm{F} \text { and } 22 \% \text { RH and are suitable for Environmental } \\
\text { Condition B application. } \\
\text { 2. Maintain pressure boundary after Seismic event. } \\
\text { W-441-P5, Rev. } 2 \text {, Appendix I, page I-2, provides a seismic } \\
\text { testing plan for these components at a seismic spectra } \\
\text { TBD. } \\
\text { 3. Pressure test at } 110 \% \text { of system design pressure of } 3000 \\
\text { psig. }\end{array}$} & \multicolumn{3}{|c|}{$\begin{array}{l}\text { Acceptance Method: } \\
\text { 1. Special Test and Inspection } \\
\text { 1,IN for Inspection } \\
\text { 1,T for Test } \\
\text { 2. Commercial Grade Survey } \\
\text { 3. Source Verification } \\
\text { 4. Vendor/tem History }\end{array}$} \\
\hline
\end{tabular}


Title: ASHCROFT PRESSURE SWITCH - MONITOR FOR LOW SCHe SUPPLY BOTTLE PRESSURE

\section{Approvals:}

Designated Engineer. Lan $/ 2 / 2 / 28$

Design Authority. RuAitelum of $12 / 21 / 98$

QA Engineer. To Dap $12 / 21 / 98$ 
Commercial Grade Item Upgrade Dedication Form Rev. No. $0=N F-3927$

ECN No. NA CGI No. CGI-SNF-D-13-P5-030

Page 6 of 12

Title: ASHCROFT PRESSURE SWITCH-MONITOR FOR LOW SCHe SUPPLY BOTTLE PRESSURE

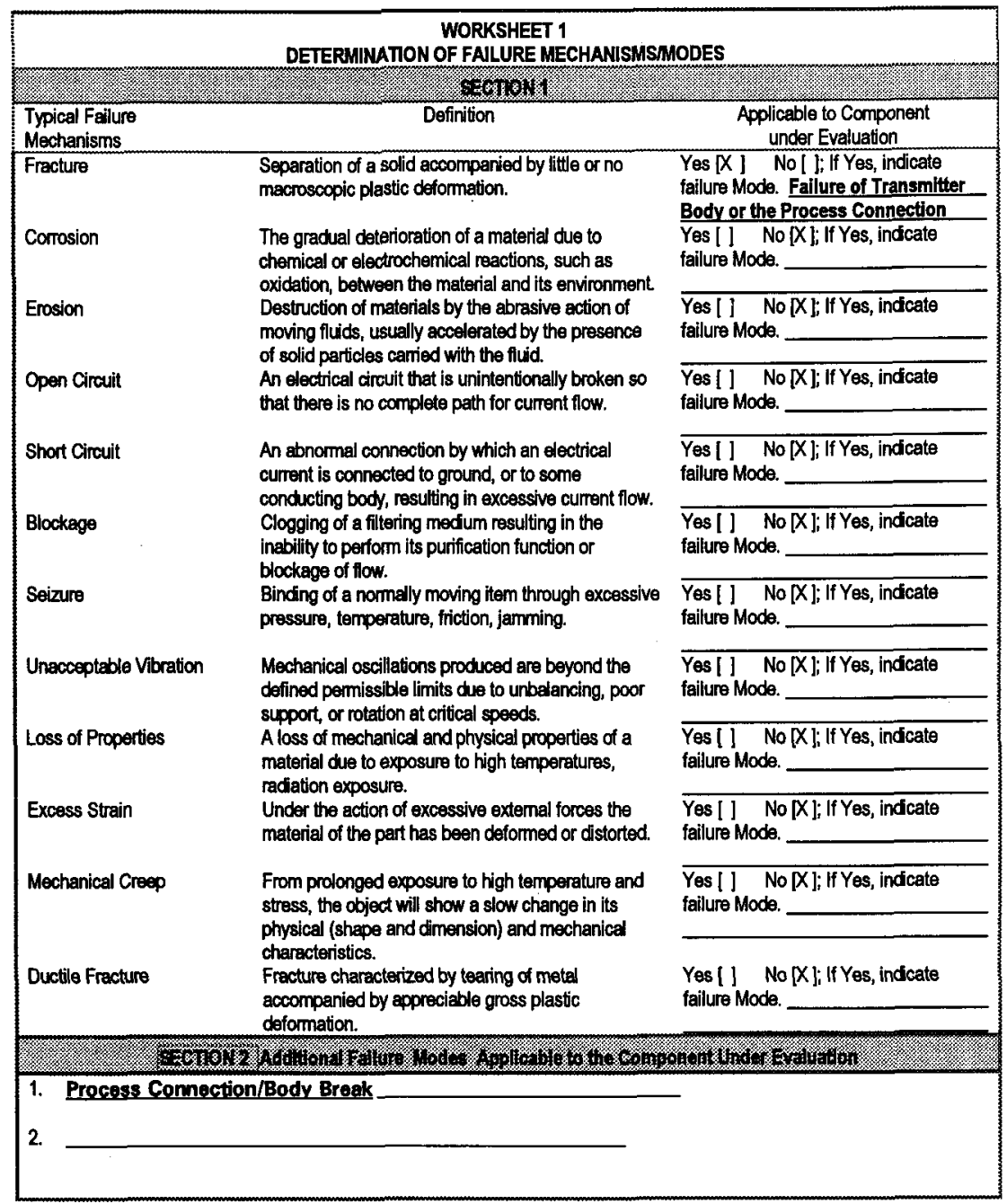


Title: ASHCROFT PRESSURE SWITCH-MONITOR FOR LOW SCHe

\section{SUPPLY BOTTLE PRESSURE}

\section{CHECKILIST 1 \\ ACCEPTANCE METHOD 1}

SPECIAL TESTIINSPECTION VERIFICATION

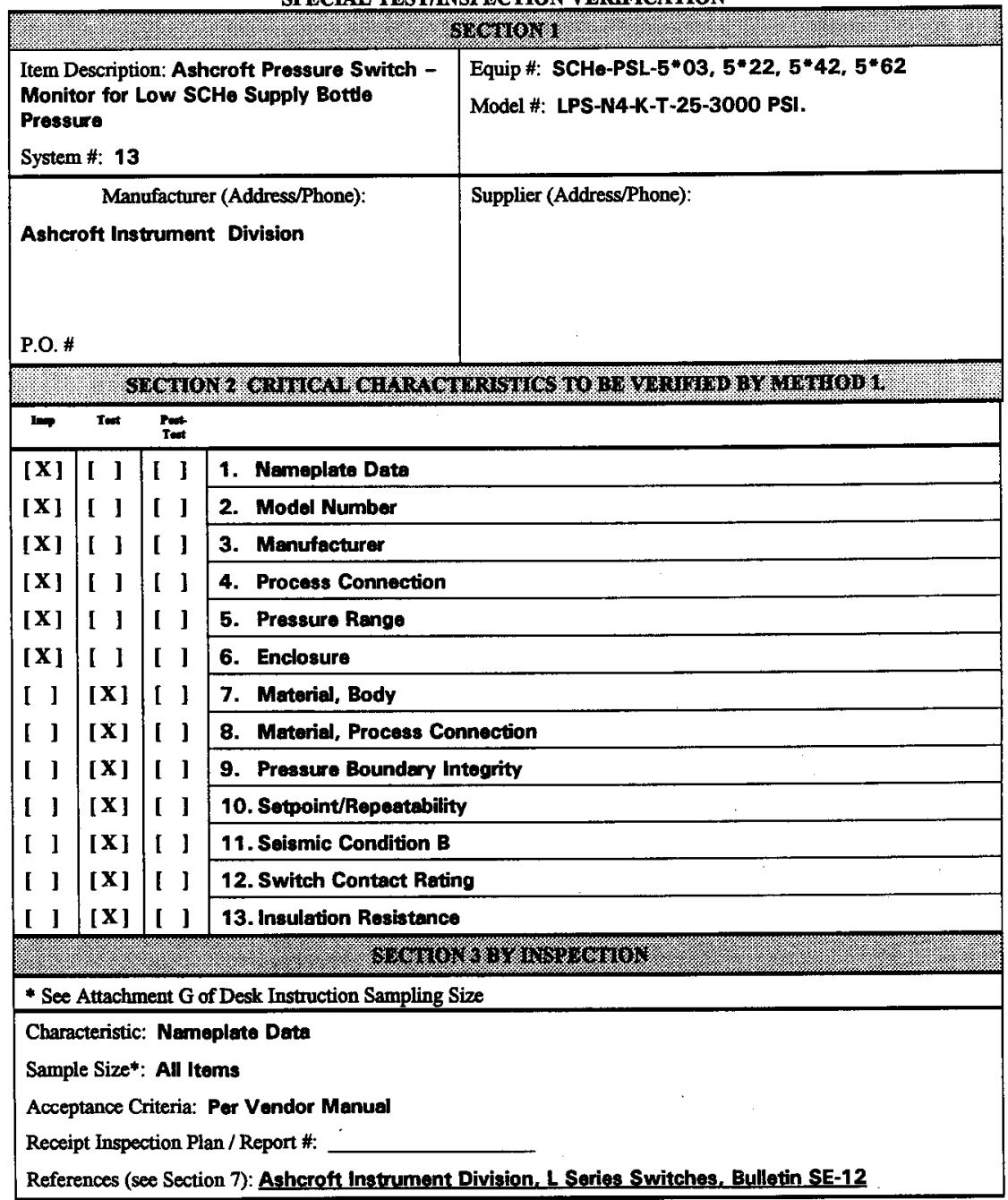


Title: ASHCROFT PRESSURE SWITCH-MONITOR FOR LOW SCHe

\section{SUPPLY BOTTLE PRESSURE}

Characteristic: Model Number

Sample Size*: All Items

Acceptance Criteria: LPS-N4-K-T-25-3000 PSI

Receipt Inspection Plan / Report \#:

References (see Section 7):

Characteristic: Manufacturer

Sample Size*: All Items

Acceptance Criteria: Ashcroft Instruments

Receipt Inspection Plan / Report \#:

References (see Section 7):

Characteristic: Process Connection

Sample Size*: All Items

Acceptance Criteria: 1/4 Inch FNPT

Receipt Inspection Plan/Report \#:

References (see Section 7):

Characteristic: Pressure Rango

Sample Size*: All Items

Acceptance Criteria: 0-3000 PSIG

Receipt Inspection Plan / Report \#:

References (see Section 7):

Characteristic: Enclosure

Sample Size: All Items

Acceptance Criteria: NEMA 4,4X

Receipt Inspection Plan / Report \#:

References (see Section 7):

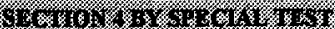

* See Attachment G of Desk Instruction Sampling Size

Test To Be Performed by:

[ ] Purchaser

[ ] Supplier/Manufacturer**

Number of Items to be Tested:

Test/Inspection Location:

[ ] Other

Characteristic for Test: Material, Body

Acceptance Criteria: Stainless Steel

Sample Size*: Normal Sampling Size

Actual Test Value:

Test Plan and Report \#: References (see Section 7): 
Commercial Grade Item Upgrade Dedication Form

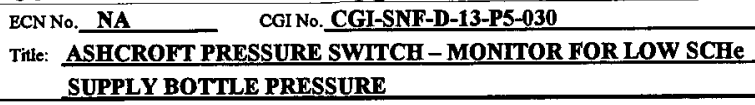

Title: ASHCROFT PRESSURE SWITCH-MONITOR FOR LOW SCHe SUPPLY BOTTLE PRESSURE

Characteristic for Test: Material, Process Connection

Acceptance Criteria: Stainless Steel

Sample Size*: Normal Sampling Size

Actual Test Value:

Test Plan and Report \#: References (see Section 7):

Characteristic for Test: Pressure Boundary Integrity

Acceptance Criteria: No Leakage at Test Pressure of 3300 Psig

Sample Size*: Normal Sampling Size

Actual Test Value:

Test Plan and Report \#: References (see Section 7):

Characteristic for Test: Setpoint/Repeatability

Acceptance Criteria: 2000 Psig / +1. 1\% of Range

Sample Size*: Normal Sampling Size

Actual Test Value:

Test Plan and Report \#: References (see Section 7):

Characteristic for Test: Seismic Condition B

Acceptance Criteria: Maintain Pressure Boundary After Seismic Event. W-441-P5, Rev. 2, Appendix I, page I-2, provides a seismic testing plan for these components at a seismic spectra TBD.

Sample Size*: Normal Sampling Size

Actual Test Value:

Test Plan and Report \#: References (see Section 7):

Characteristic for Test: Switch Contact Reting

Acceptance Criteria: Nominal 15 AMPS At 120 VAC, Less Than 0.5 VOLT Drop Across Contacts.

Sample Size*: Normad Sampling Size

Actual Test Value:

Test Plan and Report \#: References (see Section 7):

Characteristic for Test: Insulation Resistance

Acceptance Criteria: Greater Then 10 Megohm Resistance to Ground

Sample Size*: Normal Sampling Size

Actual Test Value:

Test Plan and Report \#: References (see Section 7):

**If Supplier/Menufacturer or Other, Refer to CGI Checklist-2 for Support Information 


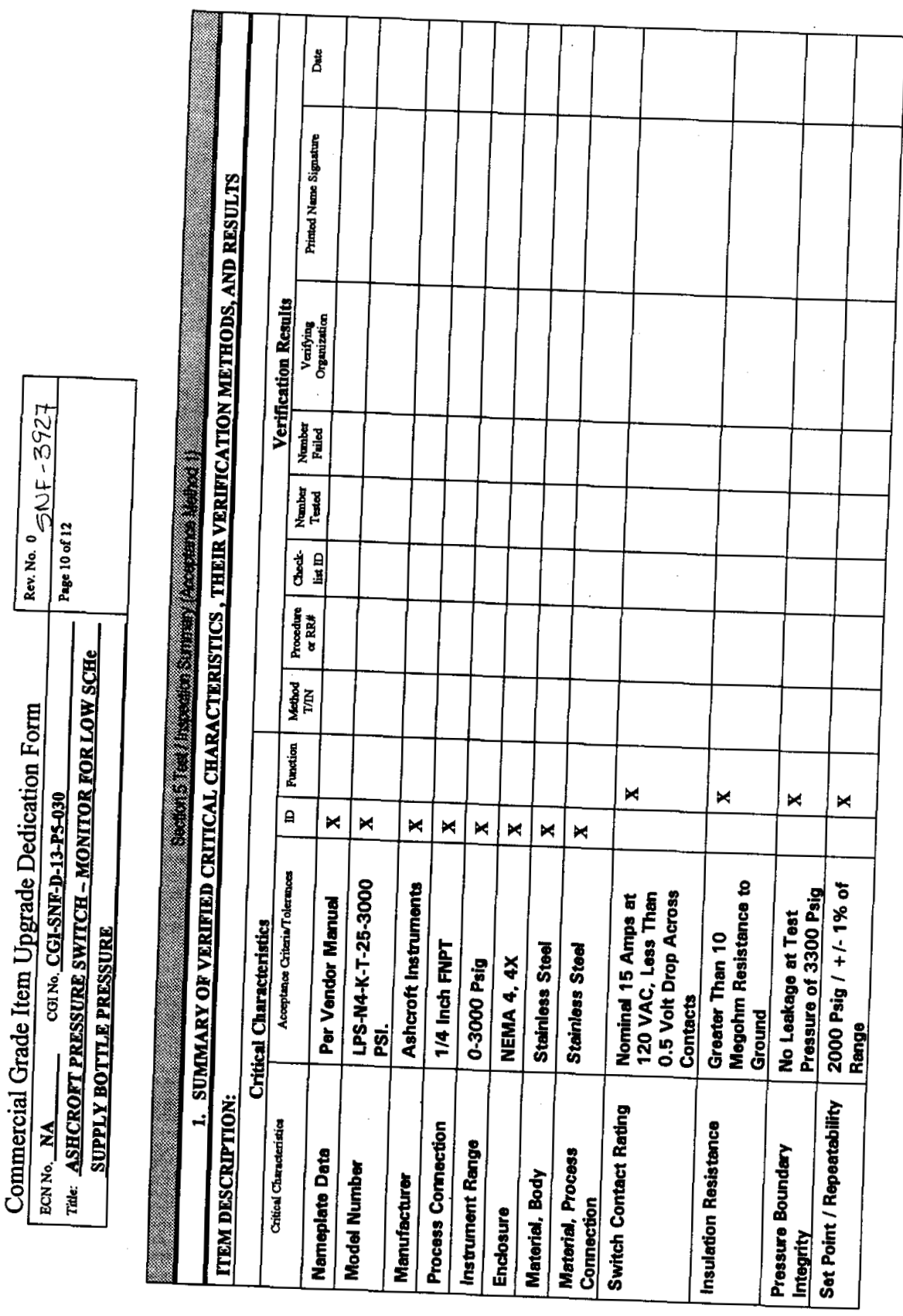

ฝัติ

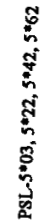




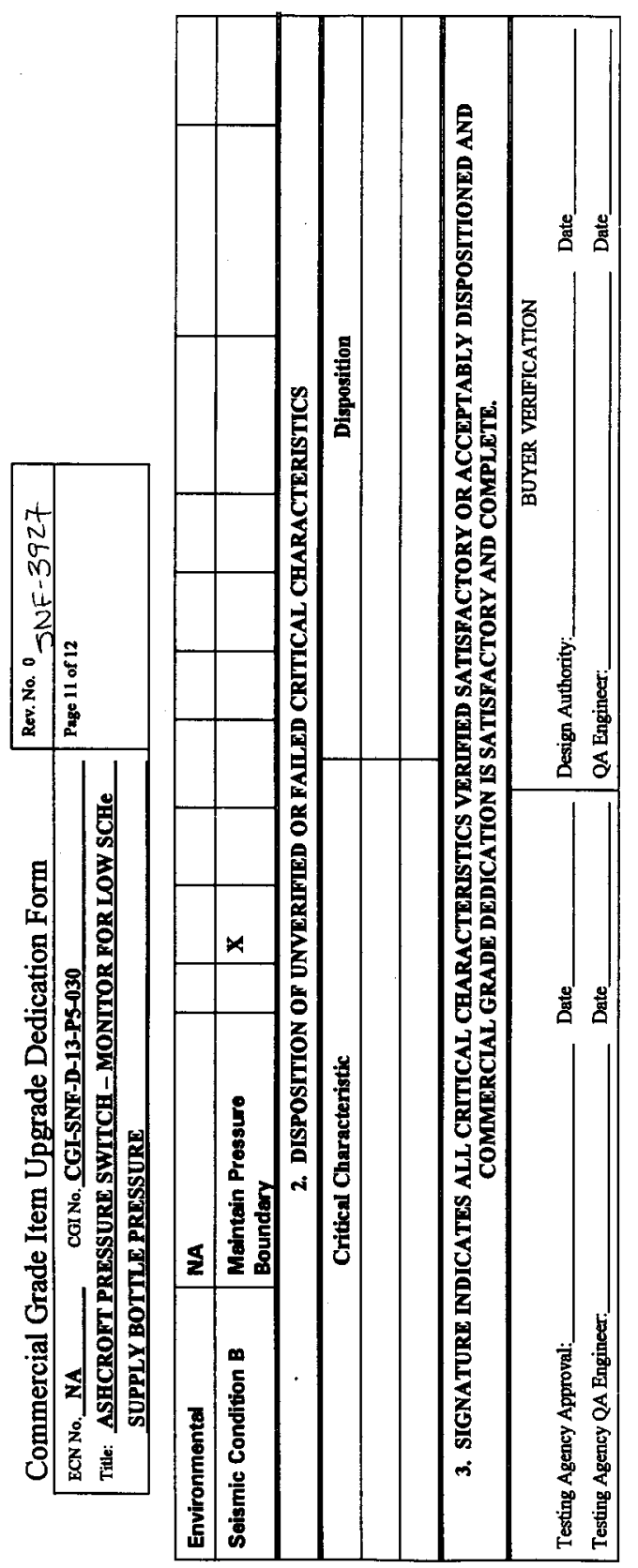


Title: ASHCROFT PRESSURE SWITCH-MONITOR FOR LOW SCHe SUPPLY BOTTLE PRESSURE

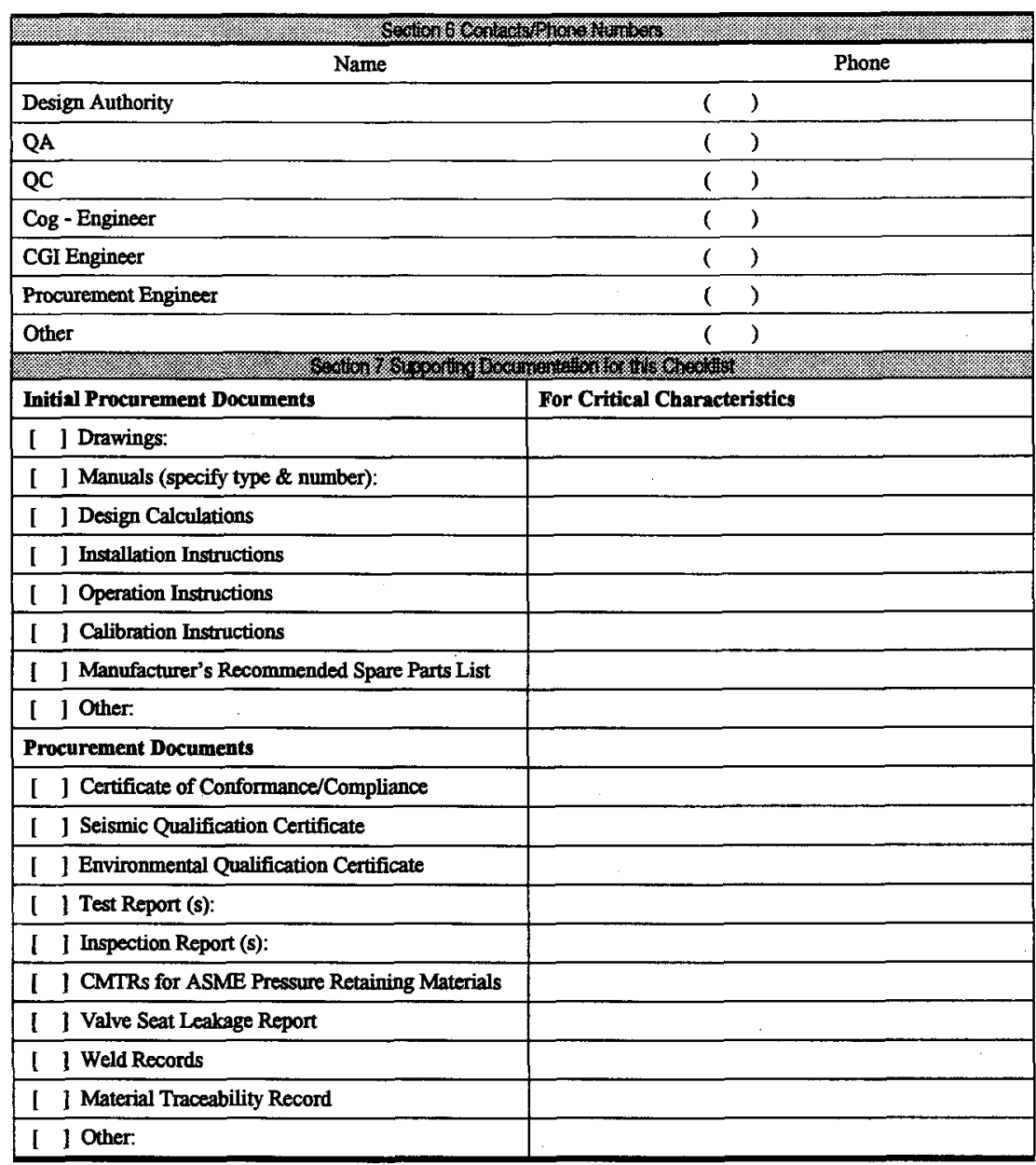

